\title{
Rancangan Aplikasi Integrated Online Ujian Berbasis E-learning Studi Kasus SMK Bintan Insani
}

\author{
Randy Rozali ${ }^{1}$, Iim Eldapendra ${ }^{2}$ \\ 1,2 Jurusan Teknik Informatika STT Indonesia Tanjungpinang \\ Jln. Pompa Air No. 28 Tanjungpinang Kepulauan Riau Indonesia \\ ${ }^{1}$ randy78mbul@gmail.com, ${ }^{2}$ iim@sttindonesia.ac.id
}

\begin{abstract}
Intisari: Dalam dunia pendidikan, sarana internet ini telah digunakan untuk jalur informasi dan teknologi yang cepat, akurat dan bersifat global. Jumlah pengguna internet dalam dunia pendidikan semakin banyak dan akan terus berkembang seiring dengan perkembangan dunia pendidikan yang mengarah kepada konsep web-based application. Hal ini juga dapat dilihat juga pada beberapa perguruan tinggi, yang menyediakan fasilitas -fasilitas yang berbasis web, yang pada dasarnya bertujuan untuk dapat memberikan banyak manfaat kepada para mahasiswa dan masyarakat umum Dengan demikian penulis tertarik untuk membuat sebuah aplikasi ujian yang memudahkan siswa dan guru dalam mengerjakan soal dan membuat soal ujian. Sistem yang dibuat ini adalah sistem yang memudahkan guru dalam membuat laporan ujian siswa Dalam perancangan ini metodologi penelitian yang digunakan adalah pengumpulan data. Metode pengumpulan data terdiri dari studi kepustakaan dan eksperimen. Rancang Bangun Aplikasi Integrated Online Ujian Berbasis E-learning Studi Kasus SMK Bintan Insani ini diimplementasikan berdasarkan analisis kebutuhan dengan menggunakan bahasa pemograman PHP, PHP MySql sebagai tempat penampung database.
\end{abstract}

Kata kunci: E-learning, Online, Ujian, PHP MySql.

\begin{abstract}
In the world of education, this Internet facility has been used for the path of information and technology that is fast, accurate and global. The number of internet users in the world of education more and more and will continue to grow in line with the development of education that leads to the concept of web-based application. It can also be seen also in some universities, which provide web-based facilities, which basically aim to provide many benefits to students and the general public. Thus the author is interested to create an exam application that allows students and teachers in working on the problem and make the exam. The system created is a system that allows teachers to create student exam reports.In this design research methodology used is data collection. The data collection method consists of literature and experimental studies. Application Design (Integrated Online Examination) Based on E-Learning Case Study SMK Bintan Insani is implemented based on needs analysis using PHP programming language, MySql PHP as a place to store the database.
\end{abstract}

Keywords: E-learning, Online, Ujian, PHP MySql.

\section{Pendahuluan}

Dewasa ini perkembangan dunia internet maju dengan pesat hal ini terlihat dengan munculnya portal-portal baru yang menyediakan berbagai macam jasa dan produk. Kehadiran portal-portal ini menambah semarak perkembangan internet di Indonesia khususnya dan dunia pada umumnya. Secara luas internet telah dimanfaatkan sebagai sarana informasi global oleh dunia usaha, politik, pendidikan dan lain-lain. Dalam dunia pendidikan, sarana internet ini telah digunakan untuk jalur informasi dan teknologi yang cepat, akurat dan bersifat global.

Jumlah pengguna internet dalam dunia pendidikan semakin banyak dan akan terus berkembang seiring dengan perkembangan dunia pendidikan yang mengarah kepada konsep web-based application. Hal ini juga dapat dilihat juga pada beberapa perguruan tinggi, yang menyediakan fasilitas fasilitas yang berbasis web, yang pada dasarnya bertujuan untuk dapat memberikan banyak manfaat kepada para mahasiswa dan masyarakat umum.

Berdasarkan Undang-undang Republik Indonesia nomor 20 tahun 2003 menyatakan bahwa dalam rangka pengendalian mutu pendidikan secara nasional dilakukan evaluasi sebagai bentuk akuntabilitas penyelenggara pendidikan kepada pihakpihak yang berkepentingan. Lebih lanjut dinyatakan bahwa evaluasi dilakukan secara berkala, menyeluruh, transparan, dan sistematik untuk menilai pencapaian standar pendidikan yang ditentukan dan proses pemantauan evaluasi tersebut harus dilakukan secara berkesinambungan. Proses pemantauan evaluasi tersebut dilakukan secara terus menerus dan berkesinambungan pada akhirnya akan dapat membenahi mutu pendidikan.

Dengan berbagai keragaman yang terdapat di dalamnya yang mencakup berbagai macam aspek, antara lain tingkat ekonomi, kesempatan belajar, ketersediaan sarana dan prasarana untuk belajar, cara belajar, kecepatan belajar serta motivasi belajar diharapkan dapat mengakomodasi semua kebutuhan dari masyarakat tersebut. Salah satu permasalahan yang dihadapi saat ini adalah pada pelaksanaan ujian, yang mana setiap ujian masih menggunakan manual exam sehingga membutuhkan waktu yang lama bagi membuat soal.

\section{Metodologi Penelitian}

Metodologi penelitian merupakan suatu proses yang digunakan untuk memecahkan suatu masalah secara logis, dimana memerlukan data-data untuk mendukung terlaksananya suatu penelitian. Metodologi ini akan dijelaskan dalam bentuk pengumpulan data dan metode pengembangan sistem. 


\section{A. METODE PENGUMPULAN DATA}

Dalam pelaksanaan kegiatan pengumpulan data yang menjadi dasar dan untuk melengkapi laporan kerja praktek ini, maka digunakan teknik yang umum dalam kegiatan ilmiah, yaitu :

1. Wawancara (Interview), yaitu kegiatan berupa tanya jawab langsung dengan orang yang berkaitan dengan ujian siswa.

2. Observasi, pengamatan langsung dimana dilaksanakan penelitian

3. Studi Literatur, pengumpulan data secara tidak langsung, yaitu dengan mengumpulkan data-data mengenai ujian sekolah.

B. METODE PENGEMBANGAN PERANGKAT LUNAK

Metode pengembangan perangkat lunak yang digunakan dalam membangun aplikasi ini menggunakan model Waterfall (Classic Life Cycle) yang menyarankan pengembangan perangkat lunak secara sistematik dan berurutan yang dimulai dari tingkatan sistem tertinggi dan berlanjut ke tahap analisis, desain, pengkodean, pengujian dan pemeliharaan.

Tahapan model air terjun (waterfall) ini melingkupi aktifitas-aktifitas sebagai berikut :

1. Requirement Analysis and Definition

Merupakan tahapan penetapan fitur, kendala dan tujuan sistem melalui konsultasi dengan pengguna sistem. Semua hal tersebut akan ditetapkan secara rinci dan berfungsi sebagai spesifikasi sistem.

2. System and Software Design

Dalam tahapan ini akan dibentuk suatu arsitektur sistem berdasarkan persyaratan yang telah ditetapkan. Dan juga mengidentifikasi dan menggambarkan abstraksi dasar sistem perangkat lunak dan hubungan-hubungannya.

3. Implementation and Unit Testing

Dalam tahapan ini hasil dari desain perangkat lunak akan di realisasikan sebagai sesuatu unit program. Setiap unit akan diuji apakah sudah memenuhi spesifikasinya.

4. Integration and System Testing

Dalam tahapan ini, setiap unit program akan diintegrasikan satu sama lain dan diuji sebagai satu sistem yang utuh untuk memastikan sistem sudah memenuhi persyaratan yang ada. Setelah itu sistem akan dikirim ke pengguna sistem.

5. Operation and Maintenance

Dalam tahapan ini, sistem diinstal dan mulai digunakan. Selain itu juga memperbaiki đṛror yang tidak ditemukan pada tahap pembuatan. Dalam tahap ini juga dilakukan pengembangan sistem seperti penambahan fitur dan fungsi baru.

\section{HASIL DAN PEMBAHASAN}

\section{A.Analisa Sistem}

Analisa sistem memerlukan tahapan yang sistematis untuk mendapatkan aplikasi yang baik dan bersesuaian dengan kegunaan dan tujuannya

\section{Analisa Prosedur Pengerjaan Soal Ujian Manual}

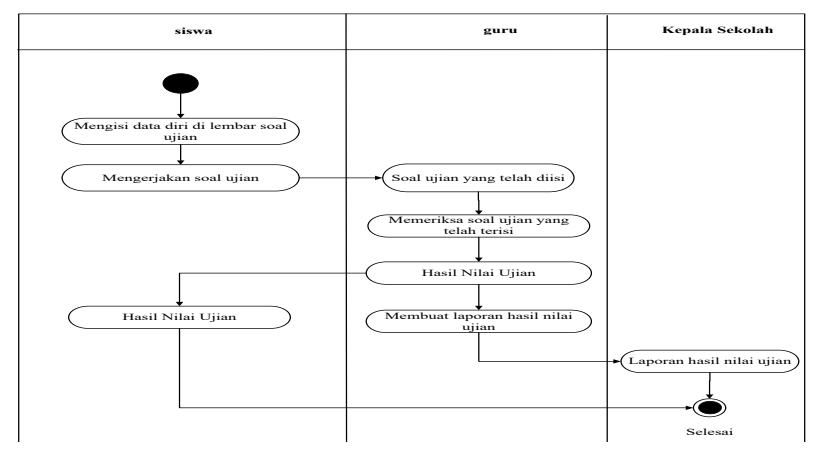

2. Analisa pengembangan sistem dengan analisa strength, weakness, opportunity, threat ( swot )

Metoda analisa SWOT bisa dianggap sebagai metoda analisa yang paling dasar, yang berguna untuk melihat suatu topik atau permasalahan dari 4 sisi yang berbeda. Hasil analisa biasanya adalah arahan / rekomendasi untuk mempertahankan kekuatan dan menambah keuntungan dari peluang yang ada, sambil mengurangi kekurangan dan menghindari ancaman. Jika digunakan dengan benar, analisa SWOT akan membantu kita untuk melihat sisi - sisi yang terlupakan atau tidak terlihat selama ini.

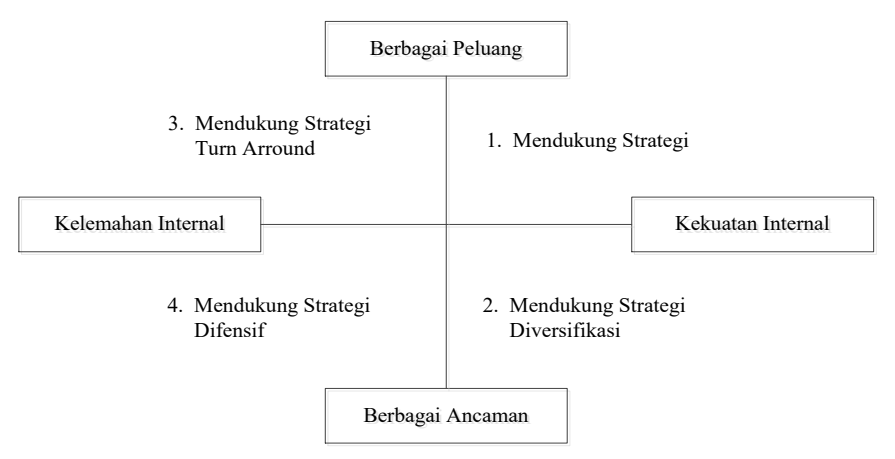

\section{A. Perancangan Sistem}

\section{Usecase Diagram Perancangan Sistem}




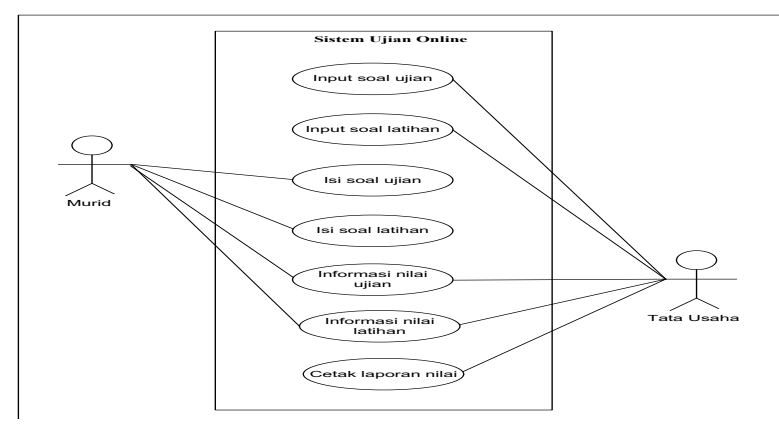

2. Activity Diagram Pembuatan Soal Ujian

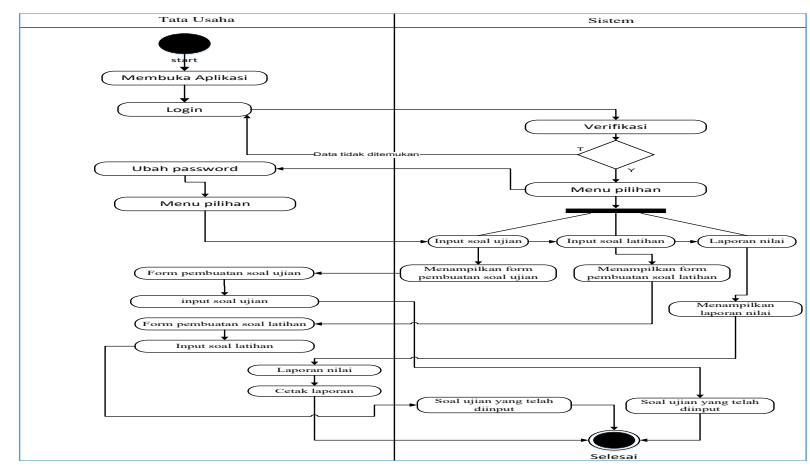

3. Squence Diagram Pengerjaan Soal Ujian

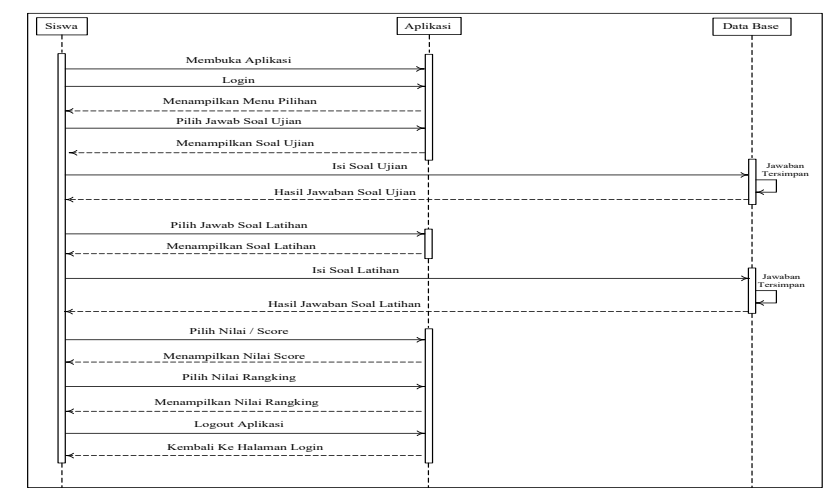

4. Class Diagram Keseluruhan Sistem

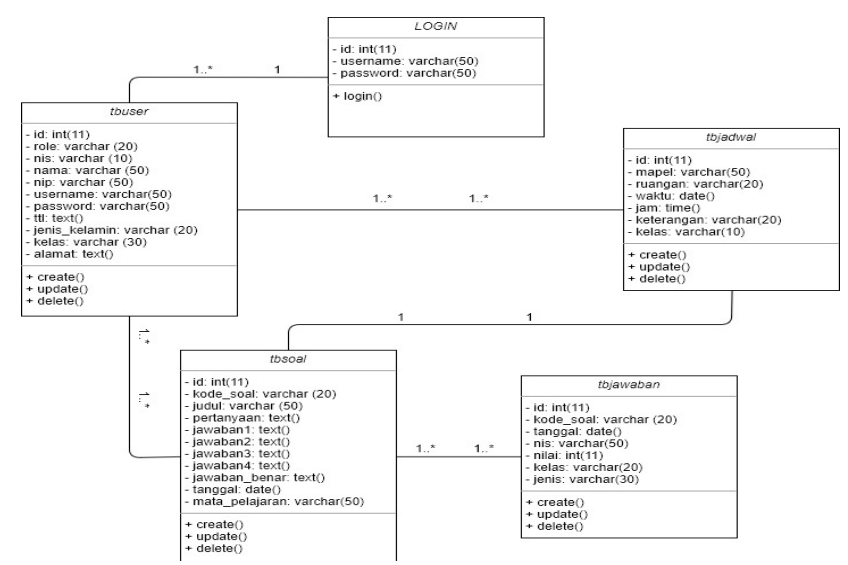

IV. KESIMPULAN

A. KESIMPULAN

Berdasarkan hasil proses perancangan dan pembuatan Rancang Bangun Aplikasi Integrated Online Ujian Berbasis E-learning Studi Kasus SMK Bintan Insani penulis menyimpulkan bahwa

1. Dengan adanya aplikasi ini maka dapat meminimalisir pengeluaran kertas yang banyak karena ujian dilakukan secara online.

2. Dengan adanya aplikasi ini maka hasil ujian lebih akurat.

3. Dengan adanya aplikasi ini dapat mempermudah dalam pembuatan laporan nilai ujian siswa secara efisien

\section{UCAPAN TERIMA KASIH}

Dalam kesempatan ini penyusun ingin mengucapkan terimakasih yang sebesar-besarnya kepada :

Ibu Ade Winarni, M.T selaku Dosen Pembimbing atas segala curahan waktu dan pemikiraannya dalam proses penyelesaian skripsi ini.

1. Bapak H.M. Lois Frederik, SE., SH., MM selaku Ketua STT Indonesia Tanjungpinang atas segala kesempatan kepada penyusun dalam menjalani pendidikan tinggi di Sekolah Tinggi Teknologi Indonesia Tanjungpinang.

2. Ibu Heti Mulyani, ST., M.Kom selaku Ketua Jurusan Teknik Informatika atas segala arahan dan tuntunan dalam proses penyelesaian masa studi yang penyusun lakukan.

3. Bapak Risora Effendi dan Ibu Eli Marni sebagai kedua orangtua yang selama ini mendoakan penyusun dan memberikan dorongan baik moral maupun materi yang tidak ternilai harganya.

4. Yoci Sherly sebagai kaka Kandung yang selama ini mendoakan penyusun dan memberikan dorongan 
baik moral maupun materi yang tidak ternilai harganya.

5. Rian Rozali, Azzura Nadhia Putri, Muhammad Ilham Sebagai Adik Kandung yang selama ini mendoakan yang tidak ternilai harganya.

6. Amanda Kartika Puri yang selalu memberikan penyusun semangat, dan tidak pernah berhenti memberikan dukungan sehingga penyusun dapat menyelesaikan skripsi ini.

7. Rekan-rekan seperjuangan khususnya Aggry Saputra, Zulfachmi, Andreas Hamonangan Pasaribu, dan Danandjaya Saputra yang selalu menyemangati penyusun, sehingga penyusun bersemangat dalam menyelesaikan skripsi ini.

8. Bapak Wanhendra Manihuruk, M.SI dan Bapak Ricak Agus Setiawan, ST., M.SI yang telah menjadi motivator untuk penyusun, hingga dapat menyelesaikan skripsi ini dengan baik

\section{REFERENSI}

[1] Anonim.Panduan KP dan TA STT INDONESIA TANJUNGPINANG, 2014, Tanjungpinang.

[2] Undang-undang Sisdiknas Nomor 20 Tahun 2003

[3] Sommerville, Ian, Software Engineering (Rekayasa Perangkat Lunak), 2011, Erlangga, Jakarta

[4] Afief Ramadhan, Hendra Saputra, PHP5 dan MySql, Elex Media Komputindo, 2005.

[5] Drs. Ir. Herry Purnomo, M. Com, Theo Zacharias, S.T, Pengenalan Informatika Perpektif Teknik dan Lingkungan, [ Penerbit ANDI, 2005 ].

[6] Hamalik, Oemar. 2007. Kurikulum dan Pembelajaran. Bumi Aksara, Jakarta

[7] Yuana, Rosihan Ari, 2007, Membangun Aplikasi E-Learning Berbasis Web dengan PHP dan MySql, Sebelas Maret University Press, Surakarta

[8] Suteja, Bernard Renaldy, 2008, Memasuki Dunia E-learning, Informatika, Bandung

[9] Agung Mulyanto, 2009, Sistem Informasi Konsep dan Aplikasi, Pustaka Belajar, Yogyakarta

[10] Efendi, E \& H, Zhuang, 2005, E-learning Konsep dan Aplikasi, Andi, Yogyakarta

[11] Hanif Al Fatta, Analisis dan Perancangan Sistem Informasi Untuk Keunggulan Bersaing Perusahaan \& Organisasi Modern ( Yogyakarta : Andi )

[12] Wiranto Herry Utomo, Pemodelan Basis Data Berorientasi Objek, [ Andi, 2010, Yogyakarta ].

[13] Fikri Awan, Konsep Permodelan Dengan UML, [ diakses 1 Agustus 2017, Pukul 14.30 wib ].

[14] Masrul Nur, Aplikasi Penerapan Teknologi Augmented Reality Untuk Penanganan Penderita Stroke Berbasis Android [ Naskah Publikasi ].
[15] Donald Bell, The Sequence Diagram, diakses dari http://www.ibm.com/developerworks/rational/library/31 01.html [12 Agustus 2017, 07.34 WIB].

[16] Gill, I.S., Fluitman, F.,\& Dar, A. (2000). Vocational education and training reform, matching skills to markets and budgets. Washington: Oxford University Press.

[17] Hadiwaratama (2005). Pendidikan kejuruan, investasi membangun manusia produktif. Diunduh tanggal 24 September 2017, dari http://digilib.polmanbandung.

[18] Likoff.,L., Chambers.J., Fogarty.S. (2008). Encyclopedia of careers and vocational guidance, fourteenth edition. New York: Infobase Publishing

[19] Pavlova M. (2009). The vocationalization of secondary education: the relationships between vocational and technology education. In R. Maclean, D. Wilson, \& C.

[20] Chinien (Eds.), International Handbook of Education for the Changing World of Work, Bridging Academic and Vocational Learning (pp. 1805-1822). Bonn: Springer.

[21] Pavlova, M. \& Munjanganja,L.E. (2009) Changing workplace requirements: implications for education. In R. Maclean, D. Wilson, \& C. Chinien (Eds.), International Handbook of Education for the Changing World of Work, Bridging Academic and Vocational Learning (pp. 180581-96). Bon: Springer.

[22] Rojewski. J.W (2009). A conceptual framework for technical and vocational education and training. In R. Maclean, D. Wilson, \& C. Chinien (Eds.), International Handbook of Education for the Changing World of Work, Bridging Academic and Vocational Learning (pp. 1940). Bonn: Springer.

[23] Tessaring, M. (2009). Anticipation of skill requirements: european activities and approaches. In R. Maclean, D. Wilson, \& C. Chinien (Eds.), International Handbook of Education for the Changing World of Work, Bridging Academic and Vocational Learning (pp. 147-160). Bonn: Springer.

[24] Thompson, John F, (1973). Foundation of vocational education social and philosophical concepts. New Jersey: Prentice-Hall.

[25] Tilaar, H.A.R., (1999). Pendidikan kebudayaan, dan masyarakat madani Indonesia. Bandung: PT. Remaja Rosdakarya.

[26] Tilaar, H.A.R., (2002). Perubahan sosial dan pendidikan, pengantar pedagogic transformatif untuk Indonesia. Jakarta: PT. Gramedia.

[27] Wardiman Djojonegoro. (1998). Pengembangan sumberdaya manusia melalui SMK. Jakarta : PT. Jayakarta Agung Offset.

[28] Wagner, T. (2008). The global achievement gap. New York: Basic Books. 